\title{
Personality of Alcoholics and Gamblers in the Union of Clubs Of Treated Alcoholics and Gamblers
}

\author{
Lana Grbeša, Marko Martinac, Marko Romić, Nikolina Palameta, \\ Valerija Soldo \\ Center for mental health, Mostar, Bosnia and Herzegovina
}

\begin{abstract}
The aim of this study was to determine the possible differences of individual personality features between the members of clubs of treated alcoholics and gamblers in the Union Of Clubs Of Treated Alcoholics And Gamblers "Dr. Vladimir Hudolin", Mostar. The sample consisted of 19 members of clubs of treated alcoholics and 7 members of clubs of treated gamblers. For the purposes of the study, the Social-demographic Data Questionnaire, Five-factors Questionnaire, Plutchik's Emotion Index (PIE-JRS) Alcohol History Questionnaire, Behavioral Evaluation Questionnaire, Gambling History Questionnaire and Diagnostic Instrument for Gamblers had been used. The data were analyzed using X2 Test and Mann-Whitney's U-Test. The results obtained have shown that the two groups differ significantly in two personality dimensions on BFQ: openness to new experiences and thoroughness. The members of clubs of treated alcoholics (KLA) achieved higher scores in dimensions: lying and responsibility, while the members of clubs of treated gamblers (KLOK) achieved higher scores in dimensions: energy, dynamics and dominance, although the differences have not proved statistically significant. Also, we have noticed some differences in the emotional profile PIE-JRS among the members of the two groups, i.e. higher scores obtained in all of the dimensions. Generally, we might say that the results of this study have been in accordance with previous studies in this field.
\end{abstract}

Key words: alcoholic's personality, gambler's personality, emotional profile, addiction

Copyright (C) 2015 KBCSM, Zagreb

e-mail: alcoholism.kbcsm@gmail.com•www.http//hrcak.srce.hr/acoholism

\section{Introduction}

Knowing the individual personality features of pathologic gamblers and alcoholics is a necessary condition for quality clinical

Correspondence to:

Dr Marko Martinac

Centre for Mental Health

88000 Mostar, Bosnia and Hercegovina

e-mail: marko.martinac@tel.net.ba practice and psychotherapeutuc work, considering the fact that most people occasionally play games of chance and belong to the social consumers of alcoholic drinks, but only a smaller percent of them develop serious problems and addiction to them. The influence of individual personality differences to behaviour is much more pronounced in the period of adolescence. From the research done so far, it is known that there are various combinations of personality features that 
may form the dimensions which increase the risk of addictive behaviour [1].

Speaking about the personality of an alcoholic, we can find many efforts in scientific literature to search for what may be called 'pre-alcoholic' or 'alcoholic' personality. However, we cannot yet surely say that a certain trait or a feature, oe even a group of traits and features represents a firm indication that someone would develop the addiction to alcohol. However, the results of application of psychodiagnostic tests mostly show that the personality features more frequently observed in alcoholics are: schyzoid character, masochistic reactions, passivity, lack of ego organization, ambivalence and lack of clear concept of self. They show that certain personality features are slightly more often observed among the alcoholics, thus supporting the thesis that there is no unique group of personality features that can be related only to alcoholics [2].

We can not even find a comprehensive definition of alcoholism, just as we can not find the unique classification of alcoholism and the unique approach to etiology of it. The World Health Organisation defines alcoholism through the definition of a 'chronic alcoholic'. According to them, 'a chronic alcoholic is a person who had excessively used alcoholic drinks, thus developing a psychological or a physical dependence to alcohol, and displaying such mental disturbance or behavioral disturbances that indicate damage to physical or mental health, or damage to their relation to other people and their economical status' [3].

Hudolin has, for practical reasons, in his definition, stated that 'the symptoms forementioned have to be determined by means of classical medical and social diagnostic procedures. It should not be just supposed, after acquiring the data on excessive drinking, that a person suffers from chronic alcoholism." [4-5] Jelinek has made a bit broader definition of alcoholism as "every need for alcoholic drinks that causes damage to a person, social damage, or both' [5].

According to DSM-V diagnostic criteria, persistent and recurrent problematic gambling, that leads towards clinically significant damage or suffering, is manifested so that a person displays four (or more) of the following in a 12-months period: has need for gamblnig on increasingly greater sums of money to achieve the wanted excitement, uneasyness and irritability when trying to reduce or stop gambling, repeated unsuccessful efforts of gaining control over gambling or reducing or stopping gambling, is frequently preoccupied with gambling (for example, keeps thinking about the gambling experiences in the past, plays for handicap or plans the future efforts, thinks about the ways how to get money for gambling), often gambles when feeling bad (for example helpless, guilty, anxious, depressive), often comes back to get back his money the next day after he loses it gambling ('chases' his own debts), lies to hide the extent of his involvement with gambling, jeopardizes or loses an important relationship, job, educational or bussiness solution because of gambling, relies on others to obtan the money to alleviate the desperate financial situation caused by gambling [6].

Many studies so far had tried to provide an answer to the question 'which are the personality traits which increase the probability that a person would become a problem gambler'. Using the Five-factor Personality Model, Bagby and his team found that the problematic gamblers get higher scores for the factor of neuroticism and lower for the factor of responsibility. Derevensky and 
Gupta also analyzed the personality and determined that the impulsiveness and searching for excitement and tension can also predict the problematic gambling among youth. There are significant differences between the problematic and the social gamblers also concerning the three facets of characteristics - higher results for impulsiveness, lower for self-discipline and thinking-through [7-8].

MacLaren et al. Reached the similar conclusions in their study on the sample of students, where the greater risk of gambling had correlated with higher neuroticism and lower agreability and responsibility. As the main risk factors for the development of harmful consequences of gambling, the authors had mentioned negative emotions and characteristics connected with lack of inhibition. Myrseth et al. have found that neuroticism, openness to new experiences, impulsiveness and the need for strong stimulations can explain $71 \%$ variance of problematic gambling. In the study of Powell et al. (according to Hardoon, Derevensky and Gupta, 2003.), the tendency to take risks positively correlated with the level of engagement in gambling activities and had been observed primarily among the persons of male gender. [9-11] The research and the clinical practice suggest that the construct of impulsiveness represents a key-factor for understanding the problematic gambling.

The aim of this study was to determine the possible differences of individual personality features between the members of clubs of treated alcoholics and gamblers.

\section{Sample and methods}

\section{Sample}

The total number nof 26 subjects had participated in the study, half of which were males (mean age: 38 years - for treated gamblers and 51 years for treated alcoholics) fomr the Uniuon of clubs of treated alcoholics „dr. Vladimir Hudolin“ in Mostar. All of the study subjects had given their written consent to participate in the study.

The clinical sample consisted of 19 subjects diagnosed as suffering from the alcohol addiction and 7 subjects diagnosed as suffering from the addiction to gambling, aged between 19 and 61 years.

\section{Method}

In this study, we have used a battery of tests: the Social-demographic Data Questionnaire, Five-factors Questionnaire, Plutchik's Emotion Index (PIE-JRS) Alcohol History Questionnaire, Behavioral Evaluation Questionnaire, Gambler's History Questionnaire and Diagnostic Instrument for Gamblers.

Plutschik's Index of Emotions is a test of compulsory choice between 62 items in which the subject chooses between the paired combinations of 12 adjectives, defining the following personality traits: warmhearted, prone to adventures, frustrated, shy, rash, depressed, cautious, silently stewing in the inside, social, quarrelsome, obedient and insecure. By each choice of adjective, one two or three points are given to one of eight basic emotions: incorporation, protection, orientation, withdrawal, rejection, aggression, investigation, reproduction and bias. The handbook (Plutchik and Kellerman, 2000) states that the level of confidence equals over 0,90 for all scales of PIE questionnaire. That had been determined by means of test-retest procedure, on the sample of 60 women. The levels of confidence determined by means of dividing the scales in two parts (data from 200 subjects) ranged from 0,61 (scale of op- 
positionality) to 0,90 (scale of reproduction) [12].

BFQ Personality Questionnaire is an instrument measuring the personality traits from the model of 'Big Five': 'energy' (E), 'comfort' (U), 'responsibility' (S), 'emotional stability' (ES) and 'mental openness' (MO). Every personality feature is determined by two sub-dimensions related to different aspects of the same dimension. The energy factor is related to those aspects which can be found in literature under the term of extroversion. This factor is more closely determined by two subdimensions: dynamics and dominance. The factor of comfort relates to the dimensions that are mostly referred to as agreabiilty or friendship, as opposed to emnity or hostility. They are more closely determined by sub-dimensions: cooperativity/empathy and warmbeartedness/friendship. The factor of responsibility relates to the ability of self-regulation/self-control, both concerning the inhibitory aspects and the pro-active ones. This dimension is defined by sub-dimensions thoroughness and durability. The factor emotional stability relates to those features which are the oposite of what we call 'a negative emotion'. It is determined by sub-dimensions: emotional control and control of impulses. The persons getting lower scores in this dimension appear as anxious, vulnerable, sensitive, irritable, impatient and impulsive. The factor mental openness relates to the dimensions previously called by other authors: culture, intellect and openness to new experiences. This factor is defined by two sub-dimensions: openness to culture and openness to experience. The Scale of Lying consists of a total number of 12 points and may be used for the identification of distorted profiles. The Instrument consists of 132 points in total. The possible reliability (Cronbach $\alpha$ ) of individual factors measured by the questionnaire has been calculated on the normative sample for croatian standardization $(\mathrm{N}=995)$ and equals 0,75 for "energy", 0,68 for "comfort", 0,80 for "responsibility", 0,87 for "emotional stability", 0,77 for "mental openness" and 0,70 for the scale of lying [13].

The Social-demographic Data Questionnaire consisted of data on age, sex, marital status, level of education, profession and the total earnings of the family.

The Questionnaire for the Evaluation of Sociopathic Behaviour. The scale applied is recommended for use in psychiatric investigations by the group of experts of World Health Organization (WHO). The criteria for evaluating the sociopathic behaviour have been taken from the handbook of Goodwin and Guzea 'Diagnostic criteria for application in psychiatric studies'. The categories of sociopathic behaviour were: problems during the school years, confrontations with law, running away from the parental home, workplace problems. Family problems, sexual problems, aggression, other problems: loitering, frequent lying and false identification. For every category, the question has been asked if the problem had been present before the development of alcoholism as well. Positive responses to the question if the category tested had appeared during the alcoholism speak in favour of sociopathic influence of alcoholic disease [14].

The Questionnaire of Alcohol History consisted of twelve questions, related to age, sex, manner of coming to treatment, alcoholics in the parental family and in the present family, the first contact with alcohol, reasons for the first tasting of alcohol, the first getting drunk, number of treatments and reasons for the last relapse. 
The Questionnaire of Gambling History consisted of 20 'yes' or 'no' questions: seven and more of confirmative answers suggested that the patient had belonged to the category of pathological gamblers [15].

The Diagnostic Instrument for gambler's addiction consists of ten 'yes' or 'no' questions. Patients with five or more confirmative answers were categorized as pathological gamblers [16].

\section{Results}

The descriptive and statistical analysis of the results has been done using IBM SPSS, version 19. The data have been processed using $\chi 2$ Test and Mann-Whitney's U-Test.

The results obtained show that these two groups significantly differ in two dimensions of personality features: thoroughness (Graph 1) and openness to new experiences (Graph 2). The members of clubs of treated alcoholics (KLA) achieved higher scores on BFQ, specifically in following dimensions: lying and responsibility, while the members of the clubs of treated gamblers (KLOK) scored higher in following dimensions: energy, dynamics and dominance, but the differences were not statistically significant. Also, we have noticed some differences in the emotional profile PIE-JRS among the members of the two groups, i.e. higher scores obtained in all of the dimensions. (Graph 3).

\section{Discussion and conclusion}

The results obtained have shown some statistically significant differences between samples KLA and KLOK in BFQ (Five-factor Personality Questionnaire) results, namely in following dimensions: thoroughness $(p=$ 0,041) and openness to new experiences $(p=0,022)$ at the level of probability $95 \%$. For the dimension openness to new experiences, bearing in

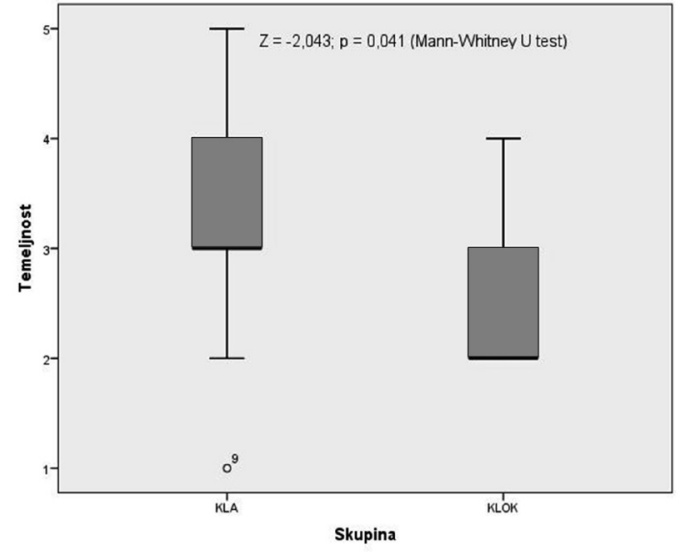

Graph 1. Differences of patterns at the scale of thoroughness of BFQ

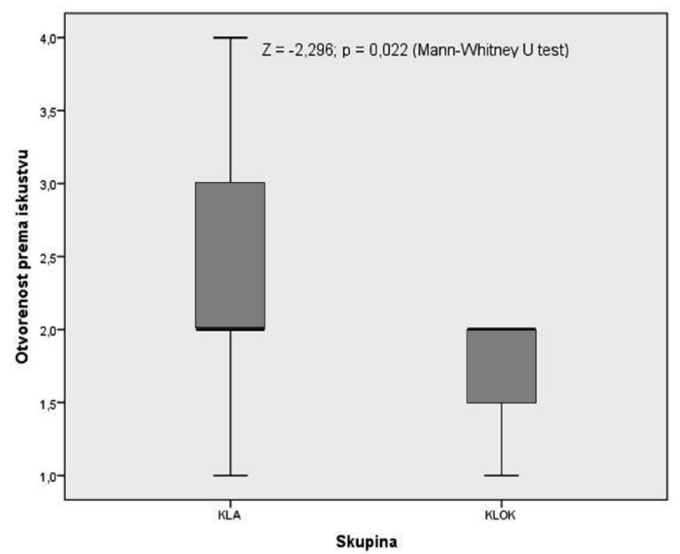

Graph 2. Difference of patterns at the scale of openness to new experience of BFQ

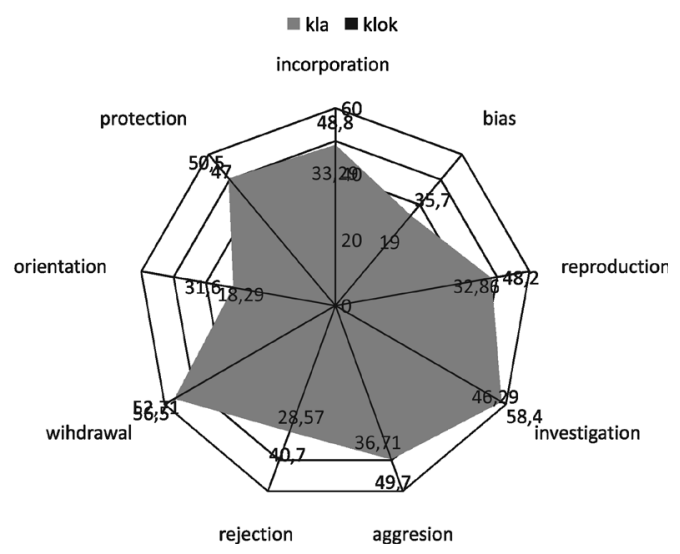

Graph. 3. Differences in the emotional profile from PIE-JRS among the members of KLA and KLOK 
mind the fact that the sample was small, we have found statistically significant differences at the level of probability of $99 \%$ as well.

The samples KLA and KLOK have also differed according to mean age (KLA $=51,5$; $\mathrm{KLOK}=38$ years) .

The differences in individual characteristics of psychopathological personality traits reflected in the fact that the members of KLOK had more problems during school years: skipping or being expelled from school and more problems later at the workplace (disciplinary measures of warning, threats of losing their jobs, confrontations with other employees and their superiors). The members of KLOK have more problems in their workplace. Also, a significant number of them reported that they had family problems, problems with aggression, deviant behaviour and sexual problems. They had no such problems before starting gambling .

$84 \%$ of treated alcoholics report that the reason for their first tasting of alcohol has been the social influence and $95 \%$ of them report that it has been also the reason for their first getting drunk. $63 \%$ of treated alco-

\section{References}

1. Dodig D. Obilježja kockanja mladih i odrednice štetnih psihosocijalnih posljedica. Doktorska disertacija. Zagreb: Pravni fakultet Sveučilišta u Zagrebu, 2013.

2. Žarković Palijan T. Značajke osobnosti alkoholičara počinitelja i nepočinitelja kaznenih djela; Medicinski fakultet, Sveučilište u Zagrebu. Doktorska disertacija, 2005.

3. World Health Organisation. Technical Report Series. No 42. Geneve: WHO, 1951.

4. Hudolin V. Ovisnost o alkoholu i drugi alkoholom izazvani poremecaji. U: Kecmanovic D, ed. Psihi- holics report, as the reason for their relapses, the lack of seriousness in their approach to treatment, reflecting in irregular attendance to club meetings and irregular taking of therapy [17].

The results obtained are in accordance with previous relevant studies from this area. Knowing the differences in personality features of alcoholics and gamblers represents a necessary condition for quality therapeutic efforts and in clinical practice, enables us to choose more adequate approaches to particular patients. In a social context, the results obtained can serve as a basis and a guideline for working with these populations in local communities. In practical context, the results may be used as a guideline for creating quality and comprehensive promotive-preventive activities in the fields of alcoholism and gambling.

\section{Acknowledgements}

None

\section{Conflict of interest}

None to declare

jatrija. Beograd - Zagreb: Medicinska knjiga, 1989: 1367-1451.

5. Jelinek EM. Phases of Alcohol Addiction. Q. J. Stud. Alcohol, 1952;13:673.

6. American Psychiatric Asssociation. Diagnostic and Statistical Manual of Mental Disorders: DSM - V. Jastrebarsko: Naklada Slap. American Psychiatric Asssociation, 2014.

7. Bagby MR, Vachon DD, Bulmash EL, Toneatto T, Quilty LC, Costa PT. Pathological gambling and the five-factor model of personality. Personality and Individual Differences 2007;43:873-880. 
8. Derevensky JL, Gupta R. The Measurement of Youth Gambling Problems: Current Instruments, Methodological Issues, and Future Directions. U: Gupta R. 4, 2004.

9. MacLaren VV. Best LA, Dixon MJ, Harrigan KA. Problem gambling and the five factor model in university students. Personality and Individual Differences 2011;50:335-338.

10. Myrseth H, Pallesen S, Molde H, Johnsen BJ, Lorvik IM. Personality factors as predictors of pathological gambling. Personality and Individual Differences 2009;47:933-937.

11. Hardoon K, Derevensky JL, Gupta R. Empirical Measures vs. Perceived Gambling Severity Among youth - Why Adolescents Fail to Seek Treatment. Addictive Behaviors 2003;28:933-946.

12. Plutchik R, Kellerman H. Indeks profila emocija. Jastrebarsko: Naklada Slap, 2000.
13. Caprara GV, Barbaranelli C, Borgogni L. Big Five Questionnaire (BFQ). Jastrebarsko: Naklada Slap, 2005.

14. Woodruff RA Jr, Goodwin DW, Guze SB. Psychiatric Diagnosis (Apendix:Diagnostic Criteria for Use in Psychiatric Research). London: Oxford University Press, 1974.

15. Winters K, Specker S, Stinchfield RDiagnostic Interview for Gambling Severity (DIGS), 1997.

16. Gamblers Anonymous questionnaires. Twenty Questions. URL: http://www.gamblersanonymous. org/20questions.html

17. Puharić Z, Kudumija Sljepčević M, Badrov T, Petričević N. Gambling among Teenagers in Bjelovar-Bilogora country (Croatia). Alcohol Psychiatry Res 2016;52:5-16.

\section{Značajke osobnosti liječenih alkoholičara i kockara u Zajednici klubova liječenih alkoholičara i kockara}

Sažetak - Cilj istraživanja je utvrđivanje eventualnih razlika u individualnim obilježjima ličnosti, članova klubova liječenih alkoholičara i kockara u Zajednici klubova Liječenih alkoholičara i kockara „, Dr.Vladimir Hudolin“ Mostar. Uzorak su činili 19 članova Klubova liječenih alkoholičara i 7 članova Kluba liječenih kockara. U istraživanju je korišten upitnik socio-demografskih podataka, petofaktorski upitnik osobnosti (BFQ), Plutchik-ov indeks emocija (PIE-JRS), upitnik alkoholne anamneze, upitnik za procjenu ponašanja, upitnik kockarske anamneze i dijagnostički instrument za kockare. Podaci su obrađeni $\chi 2$ testom i Mann-Whitney U testom. Dobiveni rezultati pokazuju da se ove dvije grupe ispitanika značajno razlikuju u dvije dimenzije osobnosti na BFQ: otvorenost prema iskustvu i temeljnost. Članovi klubova liječenih alkoholičara (KLA) postižu više rezultate na dimenzijama: laganje i savjesnost, a članovi kluba liječenih kockara (KLOK) na dimenzijama: energičnost, dinamičnost i dominacija, ali razlike nisu statistički značajne. Također, uočene su razlike u emocionalnom profilu na PIE-JRS kod članova ove dvije grupe, u smislu postignutih većih rezultata na svim dimenzijama. U cjelini, rezultati ovog istraživanja su u skladu sa prethodnim istraživanjima u ovoj oblasti.

Ključne riječi: osobnost alkoholičara, osobnost kockara, emocionalni profil, ovisnost 
